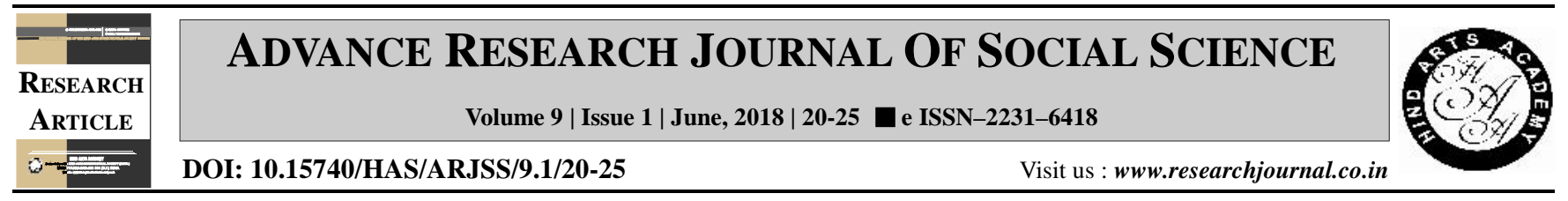

\title{
Spending time with their kids: Distribution of school going and non-school going migrant children and their family interaction
}

P.S. Sharma*, V.S. Prajapati, A.R. Parmar and S.V. Undhad

Krishi Vigyan Kendra (J.A.U.), Pipalia, Dhoraji (Gujarat) India

(Email: pinkisharma@jau.in,drvijay87@gmail.com, arvindparmar@jau.in, undhadsv@gmail.com)

\section{ARTICLE INFO :}

Received

Revised

: 19.02 .2018

Accepted

17.04 .2018

: 03.05 .2018

\section{KEY WORDS :}

Migrant, Schedule, Siblings, Interaction

HOW TO CITE THIS ARTICLE :

Sharma, P.S., Prajapati, V.S., Parmar, A.R. and Undhad, S.V. (2018). Spending time with their kids: Distribution of school going and non-school going migrant children and their family interaction. Adv. Res. J. Soc. Sci., 9 (1) : 20-25, DOI: 10.15740/HAS/ARJSS/9.1/ 20-25.

Copyright@2018 : Hind Agri Horticultural Society

*Author for correspondence

\begin{abstract}
The aim of present study as to explore the time use pattern of children of migrant labour families with their parents and other family members. A self-structured interview schedule was interviewed on mothers of the selected 120 children of age range of 68 years. In the total sample, children were composed of two groups on the basis of their school attendance. One group of children who were attending school $(n=60)$ and another group was composed of those children who were not attending school $(\mathrm{n}=60)$. Each of these two groups further subdivided with equal number of boys and girls (30 boys and 30 girls). Data were statistically analyzed by using t-test and z-test. The study showed that female children were spending significantly longer time with the mother whereas boys were significantly spending more time with the father. Mothers of the school going children spent significantly more time in different activities of the child than those of non-school going children. Mothers spent more time by watching TV or talking to their daughters as compare to their sons. Significantly more percentage of school going females performed their care activities with the help of their elder siblings as compared to very few percentage of school going males.
\end{abstract}

